\title{
Rethinking the Public Sphere in Early Modern England
}

\author{
Peter Lake and Steve Pincus
}

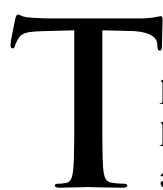

he "public sphere" has become ubiquitous in the historiography and in historically oriented literary criticism of early modern England. In this article, we argue that the phrase does have real efficacy in discussions of early modern England. However, we want to use "public sphere" in slightly different ways than most scholars have done. In particular, we argue that a narrative of the emergence of the public sphere, in the ways we will define it, can be used to talk coherently about the entire period from the Reformation into the eighteenth century.

The "public sphere" has been moving backward in time. The term "bourgeois public sphere" originally referred to a particular kind of Enlightenment discussion. However, "public sphere" now appears frequently in articles and monographs referring to the Restoration, the Interregnum, the Civil War, and it is even invading the Elizabethan and early Stuart periods. ${ }^{1}$

Steve Pincus is professor of history at Yale University, and Peter Lake is professor of history at Princeton University. This article had its origins as a position paper presented at the North Atlantic Conference on British Studies (NACBS) at Philadelphia in 2004. It was intended then, as now, to provoke comment and debate. It is therefore not a conventional journal article but rather both a critique of some recent scholarship on early modern England and a proposal for reconfiguring the period. It is far more a framework for further research than a set of firm conclusions. We are grateful for the criticism and suggestions of those present at the NACBS session, especially of the respondents John Marshall, Kevin Sharpe, and Julia Adams; the two anonymous readers; and Anna Clark. We are also grateful for discussions with Bill Bullman, Tom Cogswell, Richard Cust, Alan Houston, Ann Hughes, and Anthony Milton.

${ }^{1}$ For example, Joad Raymond, Pamphlets and Pamphleteering in Early Modern Britain (Cambridge, 2003), and "The Newspaper, Public Opinion, and the Public Sphere in the Seventeenth Century," Prose Studies 21, no. 2 (1998): 109-40; David Zaret, Origins of Democratic Culture: Printing, Petitions, and the Public Sphere in Early Modern England (Princeton, NJ, 2000); Sharon Achinstein, Milton and the Revolutionary Reader (Princeton, NJ, 1994); David Norbrook, Writing and the English Republic: Poetry, Rhetoric, and Politics, 1627-1660 (Cambridge, 1998); Nigel Smith, Literature and Revolution in England, 1640-1660 (London, 1994); Ann Hughes, Gangraena (Oxford, 2004); Brian Cowan, "Mr. Spectator and the Coffeehouse Public Sphere," Eighteenth Century Studies 37, no. 3 (Spring

Journal of British Studies 45 (April 2006): 270-292

(C) 2006 by The North American Conference on British Studies.

All rights reserved. 0021-9371/2006/4502-0003\$10.00 
Why should this be the case? Some of it no doubt has to do with scholarly fashion. Some part more, we are sure, is because scholars are always anxious to ascribe important conceptual developments to their period. We have all been chastened by debates over the emergence of the middle class, the rise of the gentry, or the development of separate spheres. Nevertheless, in this instance the reasons for the increasing deployment of the term have wider and more interesting causes than mere academic mimicry.

It seems fair to say that for many scholars working on the period before 1660 the impulse to deploy the term "public sphere" stemmed from the impact of revisionism. Revisionism, as it developed in the 1970s and after, presented scholars working on the periods both before and after 1660 with substantive and methodological challenges. ${ }^{2}$ Substantively, revisionists described the political process as court-centered, elitist, and consensual. Interestingly, this focus on court-centered elite politics and ideological consensus is exactly replicated in the nineteenth- and earlier twentieth-century Whig accounts of the later seventeenth century. These accounts emphasized the consensual, sensible, and bloodless overthrow of James II in 1688-89 by the political elite. ${ }^{3}$ This is why one prominent revisionist of early seventeenth-century history has been able to endorse G. M. Trevelyan's account of the Revolution of 1688-89. ${ }^{4}$ Thus, a similar set of issues has pushed scholars working on the period after 1660 to concern themselves with the public sphere.

Methodologically, revisionists have insisted on the primacy of manuscript materials. This was because, even when they insisted on the importance of the local, their emphasis was always placed on a kind of high politics. The high politics they described admittedly often took place outside of Westminster, but it was nearly always about the struggles and discussions of the landed elite. ${ }^{5}$ This view prompted an all-out assault on a historiography that had privileged printed sources. ${ }^{6}$ Ac-

2004): 345-66; Steve Pincus, “'Coffee Politicians Does Create': Coffeehouses and Restoration Political Culture," Journal of Modern History 67, no. 4 (December 1995): 807-34; Peter Lake and Michael Questier, The Antichrist's Lewd Hat: Protestants, Papists and Players in Post-Reformation England (New Haven, CT, 2002); Alexandra Halasz, The Marketplace of Print: Pamphlets and the Public Sphere in Early Modern England (Cambridge, 1997); Harold Love, Scribal Publication in Seventeenth-Century England (Oxford, 1993); Adrian Johns, The Nature of the Book (Chicago, 1998). There are countless others.

${ }^{2}$ In fact, for later seventeenth-century scholars the revisionist challenge was more methodological than substantive, since the revisionist account fit snugly with old Whig interpretations of that period.

${ }^{3}$ Thomas Babington Macaulay, The History of England from the Accession of James the Second, 8 vols. (New York, 1849); G. M. Trevelyan, The English Revolution, 1688-1689 (Oxford, 1938).

"John Morrill, "The Sensible Revolution," in The Anglo-Dutch Moment, ed. Jonathan Israel (Cambridge, 1991), 73-104.

${ }^{5}$ Conrad Russell, Unrevolutionary England, 1603-1642 (London, 1990), and Parliaments and English Politics, 1621-1629 (Oxford, 1979); Alan Milner Everitt, The Community of Kent and the Great Rebellion, 1640-1660 (Leicester, 1966); Mark Kishlansky, Parliamentary Selection (Cambridge, 1986); David H. Hosford, Nottingham, Nobles, and the North (Hamden, CT, 1976).

${ }^{6}$ Brian Manning, The English People and the English Revolution, 1640-1649 (London, 1976). Such a rigidly skeptical view of the printed sources of the period was a major underpinning of Mark Kishlansky's The Rise of the New Model Army (Cambridge, 1979), esp. ix-x. The attack on printed sources was not, however, limited to revisionists; see J. H. Hexter, On Historians: Reappraisals of Some of the Makers of Modern History (Cambridge, MA, 1979), esp. "The Historical Method of Christopher Hill," 227-51. For some critical comments on these issues upon which we are attempting to build, see Kevin Sharpe and Peter Lake, "Introduction," in Culture and Politics in Early Stuart England, ed. Kevin Sharpe and Peter Lake (Stanford, CA, 1993); Hughes, Gangraena. 
cording to revisionists, they studied what had really happened rather than what contemporaries claimed or perceived had happened. Only manuscript sources gave access to such knowledge, while the printed sources privileged by the likes of Christopher Hill and Brian Manning did not. ${ }^{7}$

Such distinctions between manuscript and print, between what actually happened and contemporary perceptions and claims about what happened, greatly facilitated the marginalization of ideological conflict as a major feature of this period. It became unclear what to do with the great printed sources of the seventeenth century, whether the Thomason Tracts, the vast swath of exclusion-era broadsides and ephemeral pamphlets, or later seventeenth-century memoirs, and there was a tendency in some quarters to dismiss such material as self-justificatory white noise. When revisionist historians did address printed materials, they tended to do so under the rubric of the irrational or the irreducibly religious, or as mere propaganda. ${ }^{8}$

Revisionist emphasis on contingency and high politics also tended to break up the early modern period by bracketing off the crisis years of the 1640s and 1650s from the events that preceded and followed them. The outbreak of the Civil War became the end point of many accounts, while 1660 retained its canonical status as the starting point for a host of monographs and overviews. This made good sense given the revisionist emphasis on high political contingencies and the relative absence of long-term structural causes for the great events of the period. The result was, of course, that the midcentury convulsion ceased to be conceived of as a coherent or cumulative process and became a series of contingent crises, cut off from what had come before and from what was to come later. If, as Blair Worden has pointed out, nineteenth-century British historians had fought fiercely over whether the English Revolution occurred between 1640 and 1660 or in 1688-89, some revisionists appeared to deny that there had ever been an English Revolution. ${ }^{9}$

We propose in this essay that a modified and more historically grounded conception of the public sphere allows us to reconfigure the English early modern period in ways analytically distinguishable from both revisionist and older Whig/ Marxist accounts. In doing so, we want to deploy methodological insights from

\footnotetext{
${ }^{7}$ Manning, The English People; and many works by Christopher Hill, including The English Revolution, 1640 (London, 1940), God's Englishman (New York, 1970), Intellectual Origins of the English Revolution (Oxford, 1965), and World Turned Upside Down (New York, 1972).

${ }^{8}$ John Morrill, Revolt of the Provinces (London, 1976); Conrad Russell, The Causes of the English Civil War (Oxford, 1990); Tony Claydon, William III and the Godly Revolution (Cambridge, 1996); Jonathan Scott, England's Troubles (Cambridge, 2000); Jonathan Clark, English Society, 1660-1832, 2nd ed. (Cambridge, 2000). On religious prejudice, paranoid fantasy, and myth, see Anthony Fletcher, The Outbreak of the English Civil War (New York, 1981); J. P. Kenyon, The Popish Plot (London, 1972). See also Jonathan Scott, "England's Troubles: Exhuming the Popish Plot," in The Politics of Religion in Restoration England, ed. Tim Harris, Paul Seaward, and Mark Goldie (Oxford, 1990), 107-32. Scott certainly privileges confessional conflict and English fear of popery as the motor behind political change. However, Scott is careful to distinguish his position from that of Kenyon.

${ }^{9}$ Blair Worden, Roundhead Reputations: The English Civil Wars and the Passions of Posterity (London, 2001), 17 and passim; Russell, Unrevolutionary England; Morrill, "Sensible Revolution." William A. Speck argues that there was a narrowly political, and quite conservative, revolution in 1688, but he emphatically denies that there was a social revolution in the period; William A. Speck, Reluctant Revolutionaries: Englishman and the Revolution of 1688 (Oxford, 1988), 248-51. Kevin Sharpe, while adopting a revisionist account of the causes of the Civil War, attributes genuinely revolutionary political and cultural effects to the regicide. See "A Commonwealth of Meanings," in his Politics and Ideas in Early Stuart England (London, 1989), 3-75, and Reading Revolutions (New Haven, CT, 2000).
} 
both groups. We want, in short, to explore the interactions of print and manuscript and the relationship between what "really happened" and the stories people told about what was happening. The result is to place a depiction of communicationthe relaying of accounts of political processes to different audiences-at the center of our history of the period. In particular, our deployment of the notion of the public sphere allows us to give an account of religious conflict as a major motor for political conflict and change that goes beyond that provided by the revisionists. It enables us to provide an analysis of the modes of communication and action created by religious conflict and thus to integrate religion into a wider account of political, social, and economic change without in the process collapsing religion into other categories or subordinating it to social and political interests. ${ }^{10}$ Similarly, we are able to recover political economy neither as an irreducible cause of social and political change nor as a category easily subsumed in the political or religious, but as an autonomous area of contestation in its own right. Political economy, in our account, can be understood in terms of socially anchored ideological conflict. ${ }^{11}$

\section{A POST-REFORMATION PUBLIC SPHERE?}

Jürgen Habermas distinguishes four phases of the public sphere: the ancient, the medieval (what he terms representative publicness), the bourgeois, and the degraded or transformed. ${ }^{12}$ While we find Habermas's periodization a useful heuristic device, a conceptual starting-off point, neither his rigidly stadial account nor his categories fit the patterns of historical development of early modern England as we outline them below. Rather than being a rigid application of his scheme to early modern England, what follows then is best seen as some variations on and applications of some basic themes and categories from Habermas, with a rather different account and chronology. In particular, we introduce the notion of a postReformation public sphere and mode of political maneuver and public politics. This period stretches from the 1530s through the 1630s. ${ }^{13}$ The formative period for this mode was the reign of Elizabeth I. In the period after the Reformation,

\footnotetext{
${ }^{10}$ This builds on central elements in the accounts of Puritanism as a political movement. For the Elizabethan period, see Patrick Collinson, Elizabethan Puritan Movement (London, 1967). For the outbreak of the Civil War, see Russell Causes of the English Civil War; Conrad Russell, Fall of the British Monarchies (London, 1990). For an account of the multiple media used by Puritans, see Lake and Questier, Antichrist's Lewd Hat.

${ }^{11}$ D. W. Jones, War and Economy in the Age of William III (Oxford, 1998); Steve Pincus, "The Making of a Great Power? Universal Monarchy, Political Economy, and the Transformation of English Political Culture," European Legacy 5, no. 4 (August 2000): 531-45, and "Neither Machiavellian Moment nor Possessive Individualism: Commercial Society and the Defenders of the English Commonwealth, American Historical Review 103, no. 3 (June 1998): 705-36.

${ }^{12}$ For an explication of this periodization in Habermas, see Steve Pincus, "The State and Civil Society in Early Modern England: Capitalism and Causation in Habermas's Bourgeois Public Sphere," in The Public Sphere in Early Modern England, ed. Peter Lake and Steve Pincus (Manchester, forthcoming). This argument in turn relies on a reading of Jürgen Habermas, The Structural Transformation of the Public Sphere, trans. Thomas Burger (Cambridge, 1989), esp. 52, 178.

${ }^{13}$ The notion of a long post-Reformation period is based on the research of revisionist historians of the Reformation and the notion of a long-term working out of the tensions created by the spread of Protestantism among a populace wedded to traditional ways until well into Elizabeth's reign. The problematic envisaged here draws heavily on the work of Patrick Collinson; see esp. his Birthpangs of Protestant England (New York, 1988).
} 
issues of religious identity and division came together with issues of dynastic and geopolitical rivalry to create a series of public spheres. The most spectacular examples of such behavior were often overtly oppositional, the work of Protestant opponents of a Catholic regime and then of Catholic opponents of a Protestant one, or of Puritan critics of the national church. ${ }^{14}$ However, as recent research has revealed, many of the first and most sophisticated attempts to appeal to and mobilize various publics emanated from the center of the regime itself. These appeals were intended either to induce the queen to take actions that she did not wish to take or to prevent her from doing things that she wanted to do. Thus, opinion was mobilized both in and outside Parliament to persuade her, among other things, to marry, settle the succession, kill Mary Stuart, restrain her Catholic subjects, and reform her church. In the late 1570 s, similar attempts were launched to prevent her from marrying the Duke of Anjou. Traditionally such activities were seen as the product of an often-Puritan opposition. ${ }^{15}$ More recent (revisionist) scholarship has seen them, quite rightly, as largely orchestrated by central members of the regime and their clients. This change of perspective locates the likes of William Cecil as well as the erstwhile Puritan Thomas Norton at the center of the development of novel techniques of political maneuver and communication that we argue helped to frame the post-Reformation public sphere. ${ }^{16}$ The repeated willingness of members of the establishment to resort to these novel and potentially destabilizing techniques is explained by the hothouse atmosphere attendant upon Collinson's Elizabethan exclusion crisis (and arguably the succession crisis that followed it). ${ }^{17}$

These appeals by elements of the regime to the people or to the Protestant Nation were prompted in large part to meet the threat posed to the state by Catholicism. Accordingly, they elicited a variety of Catholic replies; Catholics challenged the legitimacy of the regime and its treatment of its Catholic subjects by preaching, printing pamphlets, circulating manuscripts, and spreading rumors. These challenges were met in their turn not merely by repression-although repression in plenty there was-but also by replies using the same media and the same styles of argument. ${ }^{18}$ The regime had used persons of a markedly puritan cast of mind as agents and intermediaries, both in opposing Catholicism and in mobilizing opinion in and outside Parliament to influence the queen. In turn, the Puritan movement itself grew out of the free-lance activities of such men and their often rather more radical friends and allies. In effect, the Puritans used the same

\footnotetext{
${ }^{14}$ The classic study of this is Patrick Collinson's account of Presbyterian attempts to reform the English church from within in his Elizabethan Puritan Movement.

${ }^{15}$ J. E. Neale, Elizabeth I and Her Parliaments, 2 vols. (London, 1957-58).

${ }^{16}$ Michael Graves, "Thomas Norton the Parliament Man," Historical Journal 23, no. 1 (1980): 17-35, "The Common Lawyers and the Privy Council's Parliamentary Men of Business, 1584-1601," Parliamentary History 8 (1989): 189-215, and "The Management of the Elizabethan House of Commons: The Council's Men of Business," Parliamentary History 2 (1983): 11-38. But also see Patrick Collinson, "Puritans, Men of Business, and Elizabethan Parliaments," Parliamentary History 7 (1988): $187-211$.

${ }^{17}$ Patrick Collinson, "The Monarchical Republic of Queen Elizabeth I," in Bulletin of the John Rylands University Library of Manchester 69, no. 2 (1987): 394-424, and "The Elizabethan Exclusion Crisis and the Elizabethan Polity," Proceedings of the British Academy 84 (1994): 51-92.

${ }^{18}$ Peter Lake and Michael Questier, "Puritans, Papists, and the 'Public Sphere' in Early Modern England," Journal of Modern History 72, no. 3 (2000): 587-627, and "Agency, Appropriation and Rhetoric under the Gallows," Past and Present, no. 153 (1996): 64-107.
} 
techniques of argument and propaganda against the regime that the regime itself had habitually used to defend itself against Catholicism. ${ }^{19}$ Under the rubric of the commonwealth, a range of issues concerned with the workings and maintenance of the social order were also discussed. ${ }^{20}$ A number of revisionist historians of the Elizabethan parliament have been at pains to point out that among that institution's most central functions was the transmutation of a variety of local, private, and conciliar complaints and concerns into legislation about commonwealth matters. In our conception, such activity can usefully be seen as in itself constitutive of a sort of public sphere. We are describing, then, a series of exchanges not so much between the rulers and the ruled as between elements within the regime and their allies, clients, and connections. These exchanges varied from the quotidian to the controversial and even the allegedly seditious. Nevertheless, they all involved the same polemical and communicative strategies and in that sense constituted a postReformation public sphere. ${ }^{21}$

The legitimation for these political interactions came from two sources. It came in the first instance from notions of counsel giving, deliberation, political participation, the right to petition, and the service of the commonweal, all of which were established elements in the political culture of the late Middle Ages. These notions, we now know, were significantly modified-in large part by the use of classical tropes and rhetorical forms-for deployment in Elizabethan politics. ${ }^{22}$ Classical definitions of active political virtue and its discharge in the service of the general welfare were very often mixed and merged with Puritan or hot Protestant notions of the godly magistrate to form an ideal of the Commonwealthsman, or patriot. The public performance of the patriot's service to his country, commonwealth, and monarch did a great deal to bring the local to the national and the national to the local, in the process helping to construct an arena for the public discussion of political and religious issues. ${ }^{23}$ The second source of legitimation

\footnotetext{
19 These themes and claims are elaborated and substantiated in Peter Lake, "Public and Popular Politics: The Monarchical Republic of Elizabeth I Defends Itself," in Lake and Pincus, The Public Sphere in Early Modern England, and "The Monarchical Republic of Elizabeth I Redefined (by Its Victims) as a Conspiracy," in Conspiracies and Conspiracy Theory in Early Modern Europe, ed. Barry Coward and Julian Swann (London, 2004), 89-114.

${ }^{20}$ David Dean, Law-Making and Society in Late Elizabethan England (Cambridge, 1996). Comparison of such activity between, say, the 1590s and the 1690s reveals not only that this is the beginning of a long-term trend but also that the volume and range of such activity was so much greater in the later period as to constitute a different form of political practice. See Perry Gauci, The Politics of Trade (Oxford, 2001), 211-12.

${ }^{21}$ Paul Slack highlights the change in discussions of the public good in the 1640s and 1650s in his From Reformation to Improvement: Public Welfare in Early Modern England (Oxford, 1999), 82-101. See also Joan Thirsk, Economic Policy and Projects: The Development of a Consumer Society in Early Modern England (Oxford, 1978). The way in which the older commonwealth discourse is substantively and analytically transformed over the course of the period is the subject of Blair Hoxby's Mammon's Music (New Haven, CT, 2002).

${ }^{22}$ Markku Peltonen, Classical Humanism and Republicanism in English Political Thought, 1570-1640 (Cambridge, 1995); Stephen Alford, The Early Elizabethan Polity (Cambridge, 1998); David Colclough, Freedom of Speech in Early Stuart England (Cambridge, 2005).

${ }^{23}$ Richard Cust, “'The Public Man' in Late Tudor and Early Stuart England," in Lake and Pincus, The Public Sphere in Early Modern England; and Richard Cust and Peter Lake, "Sir Richard Grosvenor and the Rhetoric of Magistracy," Bulletin of the Institute of Historical Research 54 (1981): 40-53. The two types of character and discourse, the Puritan zealot and the classicizing self-appointed public man, were separated out and viciously satirized by Ben Jonson in Bartholomew Fair, through the characters
} 
derived from religious disputation or controversy and polemic. The disputes conducted therein centered on publicly canvased argument, conducted within certain conventions about what counted as effective or legitimate, and commonly accepted proof texts and sources of authority. The conviction was that discussion conducted within these rules would allow error to be identified and truth to prevail. At stake were certain acknowledged public goods-the interests of the commonwealth and of true religion and the defense of orthodoxy or legitimate authority. These public ends were to be furthered through different parts of the commonwealth talking to one another: on the one hand, the subject (in reality diverse interest groups) petitioned for redress of grievances, and, on the other hand, elements within the establishment appealed for support to further their own versions of the polity and the public good.

The post-Reformation public sphere, then, provided the arena for discussion of both religious and nonreligious issues. Nevertheless, we maintain that commonwealth talk in the Elizabethan period was conceptually distinct from discussions of political economy in the 1690s. Comparison between discussions of public welfare in the 1590s and those in the 1690s reveals not only that the Elizabethan period marks the beginning of a long-term trend but also that the volume and range of such activity were so much greater in the later period as to constitute a different form of political practice. ${ }^{24}$

While concerned with the public or common good, such discussions in the 1590s should ideally have taken place in private, that is to say, in closely controlled arenas of public discussion closed off from the gaze of the multitude. The institution of parliament is perhaps the crucial example of the paradoxes involved here. The discussions of the quintessentially public institution where the representatives of the realm discussed and transacted the business of the commonwealth were, notionally at least, entirely private. Only members of the House could contribute to or even witness the debate, and it was an offense to spread news of the institution's proceedings outside that charmed circle. Here and in the Privy Council state and commonwealth matters were supposed to be discussed, policy formulated, and counsel given. Increasingly, as the period ran its course, these conventions and rules were acknowledged almost as much in the breach as in the observance. From the Elizabethan period on, the supposedly private proceedings in parliament were brought to wider and wider audiences through the circulation of manuscript separates and newsletters. ${ }^{25}$ Speakers themselves often disseminated accounts of speeches, and members informed their constituents and others of their doings. By the early Stuart period, such texts were being collected in manuscript accounts of particular parliaments. ${ }^{26}$ Moreover, during moments of perceived crisis or emergency, members of the regime, its supporters, loyal opposition, and overt critics and opponents all resorted to religiopolitical controversy and making public pitches. Print, the pulpit, performance, and circulating manuscripts were all used to address promiscuously uncontrollable, socially heterogeneous, and, in some

of Zeal of the Land Busy and Adam Overdo. The public stage played a crucial part in the creation of public sphere that we are describing; Lake and Questier, Antichrist's Lewd Hat, esp. chap. 14.

${ }^{24}$ Gauci, The Politics of Trade, 211-12.

${ }^{25}$ A manuscript separate was a document - a parliamentary speech, a letter, a scurrilous poem, a news item-that was circulated on its own and often collected and transcribed in a commonplace book.

${ }^{26}$ See the discussion of the issues by Harold Love in his Scribal Publication, 9-22. 
sense, popular audiences. Such activity implied the existence of, and indeed notionally at least called into being, an adjudicating public or publics able to judge or determine the truth of the matter in hand on the basis of the information and argument placed before them.

This post-Reformation period can fairly be said to have fostered public spheres of sorts-spaces for or modes of communication or making pitches in which appeals to a general audience were made through a variety of media, appealing to a notion of the public good (or religious truth). These appeals were justified as much by the quality of the pronouncements as by the status of the pronouncer, and they necessarily called into being an adjudicating public (or publics). The legitimacy of such activities was always in question; they were never assumed to be a normal or regular feature of political life. Rather, they represented emergency measures, resorted to, in extremity, by a variety of groups anxious to push their case with the prince and/or the people. When adopted by one's opponents or those of whom one disapproved, such matters represented a form of "popularity," a dangerously seditious appeal to the people inimical to good order and monarchical rule. ${ }^{27}$ When resorted to by one's self, they either represented the continuation of loyalty and obedience by other means or were accidents, occasions when private documents, letters, apologias, or position papers intended for restricted circulation spilled out into the public domain and sometimes even into print. The earl of Essex, for one, became an expert in the circulation and manipulation in manuscript of such ostensibly private documents for what were public political purposes. Indeed, in this period, the leaked and circulated private letter became an acknowledged means of surreptitiously going public. ${ }^{28}$ Such transactions took place through the circulation and scribal publication of manuscript material, alerting us to the fact that print was not necessarily central to this public sphere. In fact, when material intended for circulation in this mode found its way into print, it often indicated the failure of the initial polemical strategy, a breach of decorum that could prove fatal to the initial political project.

Accordingly, recourse to such methods was very often accompanied, and indeed legitimated, by a variety of conspiracy theories. For it was only the incipient triumph of some conspiracy of (papist, Puritan, or corrupt court-based) evil counsel that could justify recourse to political methods and appeals that so transcended the normal boundaries of counsel giving and legitimate religiopolitical communication. In each case, the notional end of such actions was not to instantiate such appeals to the public as either normal or normative but, rather, having saved orthodoxy or the commonweal, vindicated truth, and vanquished error, to return to a consensual, deferential, and hierarchical normality in which any such recourse to the

\footnotetext{
${ }^{27}$ The increasing use of scare quotes around the term "popularity" to describe the political practices being described here is a sure sign that something significant and novel was happening and that contemporaries had noticed. On popularity, see Richard Cust, "Charles I and Popularity," in Politics, Religion and Popularity, ed. Thomas Cogswell, Richard Cust, and Peter Lake (Cambridge, 2002 ), 235-58; and Peter Lake, "John Whitgift, Puritanism, and the Invention of Popularity," forthcoming in a volume of essays on the monarchical republic of Elizabeth I.

${ }^{28}$ Paul Hammer, “'The Smiling Crocadile': The Earl of Essex and Late-Elizabethan 'Popularity," in Lake and Pincus, The Public Sphere in Early Modern England; Peter Lake and Kenneth Fincham, "Popularity, Prelacy and Puritanism in the 1630s," English Historical Review 11, no. 443 (September 1996): 856-65.
} 
public would again be regarded as seditious and deviant. ${ }^{29}$ The nature of the postReformation politico-religious scene in Western Europe, the contingencies of English politics, and the structure of the English state-in its capacity to generate conflict about the nature of and relationship between public and private interestensured that a return to this normality never quite happened.

The result was that this mode of making political pitches, of maneuver and legitimation, came to play an unacknowledged but central role in the politics of the Elizabethan and early Stuart period. However, its role was by no means normalized, and recourse to such methods, particularly at moments of crisis, could prove dangerous or counterproductive. There were emerging protocols and controls, conventions to be observed when resorting to the politics of popularity, but they remained hazy and ill defined, and it was always horribly easy to fall over the edge into sedition. When Martin Marprelate used cheap print and popular modes of discourse to try to rescue the Presbyterian cause, he provoked the authorities into suppressing the Presbyterian movement. Similarly, the earl of Essex's resort to increasingly popular methods to promote his cause and to coerce or convince the queen backfired fatally. These actions confirmed his reputation for "popularity" and ambition, thus alienating the queen and playing into the hands of his rivals. Significantly, just as with Campion and Marprelate, in dealing with the threat posed by Essex, the regime did not rely only on punishment or repression but resorted to precisely the same popular methods as those used by the earl himself: print, performance, and the spread of rumor-in effect the dissemination of counter libels. ${ }^{30}$

Even when the exclusion and succession crises that helped to form this mode of political practice under Elizabeth I had been dissipated by the accession of James I, the practices themselves did not fall into abeyance. Indeed, the new reign opened with a renewed outbreak of petitioning and making pitches by Catholic and Puritan groups, as well as by the bearers of a variety of commonwealth grievances, all eager to secure the new king's attention and support. James I himself, whose structural position and political principles committed him to the view that such activities were inherently illegitimate and, indeed, subversive, also became a skilled player of precisely this sort of communicative political game. ${ }^{31}$ Even Sir Robert Cecil, a man to whom the denunciation of "popularity" came as second nature, framed the most daring political initiative of his career in terms of the exploitation of "popular" and parliamentary grievances against the fiscal policies of the crown. Responding to these grievances, he framed the Great Contract as a bargain between the crown and the subject whereby the prerogative rights of the crown would be surrendered in return for regular parliamentary taxation. When parliament men publicly consulted their constituents about the proposal, this maneuver promptly foundered. The consequence of Cecil's initiative was enhanced public discussion

\footnotetext{
${ }^{29}$ Lake, "The Monarchical Republic of Elizabeth I Redefined"; Colclough, Freedom of Speech, 211-12.

${ }^{30}$ Hammer, "The Smiling Crocadile."

${ }^{31}$ Kevin Sharpe, "Royal Authors and Royal Authority in Early Modern England," in Sharpe and Lake, Culture and Politics in Early Stuart England, 117-38; Peter Lake, "The King (the Queen) and the Jesuit: James Stuart's True Law of Free Monarchies in Context/s," Transactions of the Royal Historical Society, 6th ser., 14 (2004): 243-60.
} 
of the prerogative rights of the crown..$^{32}$ Again, interest groups like the East India Company, dependent on but not coterminous with the public authority of the crown, used a range of techniques to appeal to a variety of publics when trying to get the government to do what they wanted. ${ }^{33}$

Thus, the practices and techniques that constituted the post-Reformation public sphere became normal, though unacknowledged, parts of the political process. Yet the level of making pitches in public debate and petitioning was neither constant nor incrementally growing; rather, the size and nature of the post-Reformation public sphere was intensely dependent on political circumstance. Alastair Bellany has shown that, even during "the personal rule of James I," ostensibly private court scandal could generate a series of exchanges conducted through manuscript libel, public performance-trials, executions, and the performance of royal mercyand cheap print. ${ }^{34}$ However, it was not until the late teens and twenties of the seventeenth century that the heady mixture of international confessional conflict, domestic religious dispute, royal marriage, war, and the rise to power of a classic evil counselor combined to create a sustained pitch of public political discourse equal to that achieved in the 1590s. ${ }^{35}$ In turn, as Kevin Sharpe has shown, it was the very intensity of the political crisis of the 1620s that shaped the peculiar cultural politics of the 1630s. The crown reformed the court, commissioned performances of royal power, and mandated ritual-centered reform of the church as a series of linked maneuvers engineered to shut down the public sphere that had opened up in the previous decade. ${ }^{36}$

\section{TRANSITIONAL MOMENT}

This post-Reformation public sphere was a prerequisite for the creation of the post-Revolutionary public sphere. The transitional moment, we suggest, started with the outbreak of England's Civil Wars. These Civil Wars broke out and took the form that they did in part because the recurrently episodic instantiations of the post-Reformation public sphere helped to change the nature of politics and expand the political nation. Once war had broken out, both Royalists and Parliamentarians struggled to generate the resources necessary to secure military and ideological victory. These were wars of words as well as of guns. Almost from the

${ }^{32}$ A. G. R. Smith, "Crown, Parliament and Finance: The Great Contract of 1610," in The English Commonwealth, 1547-1640, ed. Peter Clark, Alan Smith, and Nicholas Tyacke (Leicester, 1979), $111-27$.

${ }^{33}$ Anthony Milton, "Marketing a Massacre: Amboyna, the East India Company, and the Public Sphere in Early Stuart England," in Lake and Pincus, The Public Sphere in Early Modern England.

${ }^{34}$ Andrew Thrush, "The Personal Rule of James I," in Cogswell, Cust, and Lake, Politics, Religion and Popularity in Early Stuart Britain, 84-102; Alastair Bellany, The Politics of Court Scandal in Early Modern England (Cambridge, 2002).

${ }^{35}$ Thomas Cogswell, “'Published by Authoritie': Newsbooks and the Duke of Buckingham's Expedition to the Ile de Re," Huntington Library Quarterly 67, no. 1 (2004): 1-25, “The People's Love': The Duke of Buckingham and Popularity," in Cogswell, Cust, and Lake, Politics, Religion and Popularity, 211-34, "The Politics of Propaganda: Charles I and the People in the 1620s," Journal of British Studies 29, no. 3 (1990): 187-215, and "England, the Spanish Match," in Conflict in Early Stuart England, ed. Richard Cust and Ann Hughes (London, 1989), 107-33; Thomas Cogswell and Peter Lake, "The Duke of Buckingham, William Shakespeare, and the Politics of Popularity in the 1620s," in Lake and Pincus, The Public Sphere in Early Modern England.

${ }^{36}$ Kevin Sharpe, The Personal Rule of Charles I (London, 1992), 1-63 and passim. 
outset, contemporaries of all ideological stripes resorted to the now familiar, if previously irregular, techniques of popular and public political maneuver. There was unprecedented proliferation of newsprint, polemic, propaganda, and petitioning. Petitions were not merely circulated and presented in manuscript but increasingly printed, and they were used not merely to express or organize opinion but to appeal to and manipulate it in nationally coordinated propaganda campaigns. ${ }^{37}$ Under the pressure of events, both sides further divided into a series of competing ideological factions. The process of fragmentation created by the unprecedented events of the 1640s and 1650s in turn reinforced the sustained market for news and comment. This new situation became virtually self-sustaining, as individual actors might now enter the public sphere for narrow political advantage, economic self-interest, or desire to achieve ideological hegemony. ${ }^{38}$ Increasing demand for news, information, and political comment ushered into being new forms of literary production, such as the printed newspaper. Libels and rumors that had earlier circulated in manuscript were now routinely printed. Theological disputes that had earlier been "publicly" conducted only in the private circles of the godly, through the circulation in manuscript of a variety of position papers, challenges, and responses, now went public, making the transition from the pulpit into print with dizzying speed. ${ }^{39}$

Arguably, by the 1650s this situation was no longer perceived as episodic but had come to be seen by many as unavoidable, and by some even as normal. ${ }^{40} \mathrm{It}$ is perhaps possible, and, in some reading of the period, necessary, to begin to speak of a single unified public sphere as opposed to multiple public spheres. In other words, the different kinds of political, religious, and economic gestures that emerged at different points in different episodes before this period tended now to all become regular features of political communication. During the 1640s and 1650 s, as in the Elizabethan period, factions within each camp appealed for popular support; unprompted by the great and the good, an increasingly varied range of dissident and radical groups intervened. Grandees and their often more radical supporters and clients struggled for control of the political or ideological agenda; players strategically released private correspondence and circulated scandalous libel and rumor. All these had been present during the Elizabethan period, but by the 1650s they were happening in public and in print at a rate and intensity that was completely unprecedented. What was new, we suggest, was the intensity, speed, and sheer volume of popular and public political discussion. At this point, it seems

\footnotetext{
${ }^{37}$ David Wootton, "From Rebellion to Revolution: The Crisis of the Winter of 1642/3 and the Origins of Civil War Radicalism," English Historical Review 105, no. 416 (1990): 654-69; Peter Lake, "Puritans, Popularity and Petitions: Local Politics in National Context, Cheshire 1641," in Cogswell, Cust, and Lake, Politics, Religion and Popularity, 259-89; Zaret, Origins; Achinstein, Milton, 27-70.

${ }^{38}$ Hughes, Gangraena; Raymond, "Newspaper, Public Opinion," and Pamphlets; Zaret, Origins; Jason Peacey, Politicians and Pamphleteers: Propaganda during the English Civil Wars and Interregnum (Aldershot, 2004).

${ }^{39}$ Joseph Frank, The Beginnings of the English Newspaper (Cambridge, MA, 1961); Joad Raymond, The Invention of the Newspaper (Oxford, 1996); Smith, Literature and Revolution, 21-92; Zaret, Origins; Bellany, Politics of Court Scandal, 261-78. On theological dispute, compare the account given of the prewar situation in Peter Lake and David Como, "'Orthodoxy' and Its Discontents," Journal of British Studies 39, no. 1 (2000): 35-70, with the situation described in Hughes, Gangraena.

${ }^{40}$ Steve Pincus, Protestantism and Patriotism: Ideologies and the Making of English Foreign Policy, 1650-1668 (Cambridge, 1996), esp. 87-191.
} 
fair to conclude that the post-Reformation public sphere was well on the way to becoming something else.

The Restoration period, of course, did not always exhibit the feverish levels of public discussion characteristic of the 1640s and 1650s. The public sphere continued to ebb and flow. As in the earlier period, crises-for example, the exclusion crisis or the Anglo-Dutch Wars-generated spikes in public discussion, but we see a qualitative shift. Even at its lowest points, public discussion never returned to the relative quiescence of the mid-1630s. ${ }^{41}$ Issues of religion, the constitution, the national interest, and political economy were constantly under public scrutiny. More important, many Royalists/Tories, leading members of precisely the group we might expect to be keenest to suppress the public sphere, recognized the importance of appeals to the public. ${ }^{42}$ The height of the Tory reaction in the 1680s, for example, was not a period characterized by press silence but rather by the shrill tones of Roger L'Estrange's Observator. Had James II succeeded in his plan to recast the English state, the public sphere as we are describing it here would almost certainly have been severely attenuated. ${ }^{43}$ James at various times did call for the suppression of all false news, did deploy a vast network of spies and informants to chill public criticism, did create new institutions such as the Ecclesiastical Commission to silence religious debate, and did use an increasingly professional and brutal standing army to discourage dissidents in the localities. ${ }^{44} \mathrm{How}$ ever, all indications are that James would not have relied on a court-centered polity like his grandfather but rather on a culture of incessant public adulation coupled with a sophisticated print-based propaganda regime like that of Louis XIV. ${ }^{45}$ James deployed an army of Catholic propagandists based at St. James's Palace, made use of Quaker news networks, and routinely resorted precisely to the kinds of political maneuvers pioneered episodically in the post-Reformation public sphere. ${ }^{46}$

\section{POST-REVOLUTIONARY PUBLIC SPHERE}

The type of public sphere that was emerging was socially and ideologically distinct from what went before. While a range of contemporaries still hoped to eliminate the public sphere or at least to tame it, a number of other developments made

\footnotetext{
${ }^{41}$ This is clearly shown by Mark Knights, Representation and Misrepresentation in Later Stuart Britain (Oxford, 2005), 16, and Politics and Opinion in Crisis, 1679-1681 (Cambridge, 1994), pt. 2, which demonstrates that petitioning and addressing had become highly competitive modes of propaganda dissemination; Pincus, Protestantism and Patriotism, 199-268, 276-318; John Miller, After the Civil Wars (Harlow, 2000).

${ }^{42}$ Tim Harris, London Crowds in the Reign of Charles II (Cambridge, 1987); Knights, Politics and Opinion; Susan J. Owen, Restoration Theatre and Crisis (Oxford, 1996); Philip Harth, Pen for a Party (Princeton, NJ, 1993).

${ }^{43}$ John R. Western, Monarchy and Revolution (Basingstoke, 1985).

${ }^{44}$ The extent and power of James's absolutist regime is discussed more fully in Steven Pincus, The First Modern Revolution (New Haven, CT, forthcoming).

${ }^{45}$ See, e.g., the similarities between the strategies deployed by Louis XIV—detailed by Peter Burke, The Fabrication of Louis XIV (New Haven, CT, 1992)—and those used by James II's chief publicist, Henry Care, explored by Lois Schwoerer, The Ingenious Mr. Henry Care (Baltimore, 2001).

${ }^{46}$ Steve Pincus, "The European Catholic Context of the Revolution of 1688-89," in Shaping the Stuart World, ed. Allan MacInnes and Arthur Williamson (Leiden, 2005), 79-114, and First Modern Revolution. This view is at odds with the currently conventional view of James II's rule, which is largely based on the scholarship of John Miller in James II: A Study in Kingship (Hove, 1977), 53-71.
} 
this impossible. "Political economy"-conceived of as an increasingly autonomous area of activity and concern-was becoming an increasingly central topic for public discussion. ${ }^{47}$ The vast cost of the Civil Wars themselves, as Mike Braddick has shown, required both sides in raising revenue to rely upon mobile rather than exclusively upon landed wealth. ${ }^{48}$ The new apparatuses necessary to create an infrastructure capable of fighting and sustaining professional armies and navies forced the state to tap new social resources. Since the English had learned by experience that money provided the sinews of war, debates over the best ways to raise money became an essential part of the public sphere. The scale of warfare that came into being in England in the 1640s and 1650s forced the state to recognize its permanent reliance upon financiers, merchants, and tradesmen on a scale hitherto unimaginable. ${ }^{49}$ Of course, the early Stuart state had been episodically compelled to turn to just these classes of people for financial assistance and expertise. From the 1650s, however, this reliance became an increasingly normal, indeed routinized feature of the state. In effect, the post- 1650 state came to depend on a differently configured and broader set of social groups.

These political and institutional changes need to be set alongside social and economic shifts in the second half of the seventeenth century. While most of the rest of Europe was undergoing a process of de-urbanization in the last two-thirds of the seventeenth century, England was rapidly urbanizing. Whereas between 10 percent and 12 percent of English people lived in towns in the early sixteenth century, the most recent estimates suggest that by 1700 as many as 40 percent lived in urban areas. ${ }^{50}$ England's cities and towns were setting the economic and cultural agenda. Just as important, later seventeenth-century England was more attuned to the market as a central medium of exchange. There is good reason to believe that the English had more disposable income in the later seventeenth century. Whereas over 80 percent of the population was employed primarily in agriculture in the early sixteenth century, in the later seventeenth century less than 60 percent of the population was so employed..$^{51}$ Those not employed in agriculture were necessarily paid in wages rather than in kind. These new wage earners were economically able to consume actively the exponentially increasing amounts of broadsides, pamphlets, sermons, and newssheets generated during and after the Civil Wars. All these factors can be seen coming together in the coffeehousefamously the social site in which Habermas located his rendition of the bourgeois

\footnotetext{
${ }^{47}$ See Paul Slack, "Government and Information in Seventeenth-Century England," Past and Present, no. 184 (2004): 65-66, for a defense of the use of the term "political economy" in the period.

${ }^{48}$ Michael Braddick, Parliamentary Taxation in Seventeenth-Century England (Woodbridge, 1994), 297-98.

${ }^{49}$ Braddick, Parliamentary Taxation in Seventeenth-Century England; Michael Braddick, The Nerves of State (Manchester, 1996); James Scott Wheeler, The Making of a World Power (Stroud, 1999); Steven Pincus, "From Holy Cause to Economic Interest," in A Nation Transformed, ed. Alan Houston and Steve Pincus (Cambridge, 2001), 272-98.

${ }^{50}$ C. G. A. Clay, Economic Expansion and Social Change (Cambridge, 1984), 1:165; John Langton, "Urban Growth and Economic Change: From the Late Seventeenth Century to 1841," in The Cambridge Urban History of Britain, vol. 2, 1540-1840, ed. Peter Clark, (Cambridge, 2000), 462. This is not far from William Petty's estimate of 33 percent: William Petty, "Essay about Analysis of Property," British Library, temp. James II, add. MSS 72866, fol. 54r.

${ }^{51}$ Clay, Economic Expansion, 1:165, 2:102; Carole Shammas, The Pre-industrial Consumer in England and America (Oxford, 1990), 28.
} 
public sphere. Coffeehouses had become spaces in which merchants, tradesmen, aristocrats, and clerics assembled in urban settings to discuss news, politics, and trade-political economy - while purchasing and consuming the newly fashionable exotic drinks of coffee, tea, and chocolate. ${ }^{52}$

By the 1680s it was clear that two competing visions of England's economic future had emerged..$^{53}$ Pamphlets, broadsides, economic periodicals, and widely circulated company position papers outlined increasingly demarcated positions on political economy. ${ }^{54}$ In the committee rooms of the Royal African and East India Companies, Tories and supporters of James II worked out a political economic vision in which England needed to acquire and maintain a territorial empire in order to achieve and maintain a major role in European geopolitics. Because James II and his economic fellow travelers believed wealth was ultimately based on land, they were convinced that the world's property was limited. States thus competed in a vicious game to amass as much of the world's scarce resources as possible. The alternative economic vision, enunciated most prominently in the 1680s by opponents of the East India company's trade monopoly and England's manufacturers, was that England's best hope was a manufacturing nation. The proponents of this view, mostly Whigs, argued along with John Locke that the basis of wealth was human labor, and therefore wealth was potentially infinitely expandable.

Each of these visions had clear implications for describing the contours of the public sphere. If wealth was finite, then public discussion of political economic data was itself a scarce and valuable commodity. Knowledge of the location of valuable commodities-spices, minerals, or other raw materials-needed to be hoarded by competitive states. By contrast, those who believed that manufacturing held the key to economic success needed economic information to be readily available. Only by having information about regional price variations, labor supplies, and local political constraints could manufacturers maximize commercial efficiency. When the Whig political economic vision triumphed after the Revolution of 1688-89, leading eventually to the creation of the Bank of England (1694), England's government was ultimately constrained to limit its interventions against the public sphere. Occasional interventions to limit forms of political activity were imaginable, but only within legally defined limits. ${ }^{55}$

\footnotetext{
${ }^{52}$ Pincus, “'Coffee Politicians Does Create”; Cowan, "Mr. Spectator."

${ }^{53}$ For the emergence of these views, see Robert Brenner, Merchants and Revolution (Princeton, NJ, 1993). For the political consequences of these divisions, see Gary De Krey, A Fractured Society (Oxford, 1985); and Bruce Carruthers, City of Capital: Politics and Markets in the English Financial Revolution (Princeton, NJ, 1996); Steven Pincus, "Whigs, Political Economy, and the Revolution of 1688-89," in Cultures of Whiggism, ed. David Womersley (Newark, DE, 2005), 62-85.

${ }^{54}$ For one example of a political economic periodical from the 1690s, with its origins in the $1680 \mathrm{~s}$, see Natasha Glaisyer, "Readers, Correspondence, and Communities: John Houghton's A Collection for Improvement in Husbandry and Trade (1692-1703)," in Communities in Early Modern England, ed. Alexandra Shepard and Phil Withington (Manchester, 2000), 235-51.

${ }^{55}$ William Letwin, Sir Josiah Child: Merchant Economist (Cambridge, MA, 1959), 22; W. J. Ashley, “The Tory Origin of Free Trade Policy," Quarterly Journal of Economics 11, no. 4 (July 1897): 353; K. G. Davies, The Royal African Company (London, 1957), 103-29; K. N. Chaudhuri, The Trading World of Asia and the English East India Company, 1660-1760 (Cambridge, 1978), 116; Tim Keirn, "Monopoly, Economic Thought, and the Royal African Company," in Early Modern Conceptions of Property, ed. John Brewer and Susan Staves (London, 1995), 427-66; D. W. Jones, War and Economy in the Age of William III and Marlborough (Oxford, 1988), 12-13, 296-301; Douglass North and Barry Weingast, "Constitutions and Commitment: The Evolution of Institutions Governing Public
} 
It was only after the Revolution of $1688-89$, then, that what we refer to as the fully fledged post-Revolutionary public sphere became a permanent feature of English public life. Even then, the victory of Whig political economy remained fragile in the several decades following the Revolution. The East India Company, Royal African Company, and eventually the South Sea Company continued to advocate a land-based political economy. Tory politicians working hand in hand with Jacobite activists such as John Briscoe had many opportunities to regain the political economic upper hand. Economic initiatives such as the Land Bank or political success (including the various Jacobite plots up to and including the Fifteen Rebellion) could easily have restored a Jacobite political economic vision. In this sense, England's age of revolution came to an end only after the Hanoverian succession had made the possibility of Jacobite political restoration appear remote and when the South Sea bubble had finally discredited Jacobite political economy. ${ }^{56}$

Even at this late date, public rationality appeared as an ideal to be aspired to rather than as a description of public discourse. In the earlier period, the model of rational discussion had been in large part provided by religious controversy. This controversy, of course, presupposed commonly known standards of argument, sources of authority, and proof text. In some quarters, at least, the existence of heresy and the need for public debate were regarded not only as necessary evils inherent in a fallen world but as positive goods: means whereby error could be publicly confuted and truth refined and even discovered.$^{57}$ However, the underlying model remained that of the ultimate triumph of truth over heretical error, in which the end result of controversy was an agreement on orthodoxy, a return to consensus, and an end to further discussion. Given the nonnegotiable nature of post-Reformation religious difference and the fragmentation of the 1640s and 1650s, such expectations had been consistently frustrated throughout the period. Even into the eighteenth century, many contemporaries retained such expectations of closure and quiescence. However, during the post-Revolutionary period some began to develop a genuinely openended notion of deliberatively discovered truth. Although there is no evidence that they had in any sense triumphed by 1720 , for these men and women, public discussion was a means to discover truth, not through the victory of one side over the other but through the cut and thrust of argument and the dialogic interrogations of plausible hypotheses. ${ }^{58}$

The Reformation, socioeconomic change, and state formation were all European as much as they were British problems. The narrative we have traced here, the transition from the post-Reformation public sphere to the post-Revolutionary

Choice in Seventeenth-Century England," Journal of Economic History 49, no. 4 (December 1989): 803-32.

${ }^{56}$ Daniel Szechi, The Jacobites, Britain, and Europe, 1688-1788 (Manchester, 1993); Paul Monod, Jacobitism and the English People, 1688-1788 (Cambridge, 1989); Eveline Cruickshanks, The Glorious Revolution (New York, 2000); Paul Hopkins, Glencoe and the End of the Highland War (Edinburgh, 1986). In the interim the continued survival of the post-Revolutionary public sphere had to be ensured by occasional coercive state action. Even then, the extent of Jacobitism frustrated the episodic attempts of the post-Revolution state to silence their political enemies.

${ }^{57}$ Peter Lake, "Anti-Popery: The Structure of a Prejudice," in Cust and Hughes, Conflict in Early Stuart England, 72-106.

${ }^{58}$ Pincus, "Coffee Politicians Does Create"; Knights, Representation and Misrepresentation, pt. 2; Rachel Weil, "The Politics of Informing in the 1690s: Mathew Smith versus the 'Great Men," in Lake and Pincus, The Public Sphere in Early Modern England. 
public sphere, naturally begs for comparisons. The two obvious points of comparison are France and the United Provinces of the Netherlands. We neither have space nor the requisite expertise to do anything like full justice to the comparisons called for. What follows is an attempt to provoke reflection and debate.

In France, as in England, religious struggles of the sixteenth century generated an episodic yet recurrent series of public spheres. ${ }^{59}$ The level of polemical excitement and conflict reached in France during the religious wars far exceeded anything experienced in Elizabethan England. Similarly, the political energy and public controversy produced during the Fronde arguably rivaled-in intensity if not in form-contemporary developments in England. ${ }^{60}$ Unlike in England, however, those public spheres did not morph into anything like what we are describing as the post-Revolutionary public sphere; rather, what emerged after the Fronde was the greatly strengthened monarchy of Louis XIV. ${ }^{61}$ This outcome starkly emphasizes the role of political contingency in shaping the contours of the public sphere. Despite its remarkable growth, the French monarchy, unlike the English, was able to finance itself without recourse to a newly configured social class. Intendants, it is true, provided the state with new wealth, but, unlike the English merchant and trading classes, they were invariably co-opted into a traditional hierarchical framework. The French monarchy was thus able to feed its own ravenous state without creating a dynamic class organized around mobile wealth. ${ }^{62}$

The United Provinces of the Netherlands, like England and France, had fierce, vibrant, and episodically robust post-Reformation public spheres in the sixteenth and seventeenth centuries. Religious controversies, ranging from debates between Catholics and Protestants to debates between Remonstrant and Counter-Remonstrant Protestants, periodically engaged the Dutch in town squares and in grachten spraken (canal chats). The Dutch Republic itself was formed in the crucible of warin this case an eighty-year struggle for independence against Spain. While that struggle did not, perhaps, ever create the centralized state that emerged in France or England, this should not blind us to the massive accretion of statelike bureaucracies in all of the seven provinces. If England had to turn to mobile wealth to remain a major player on the European scene in the second half of the seventeenth century, the Dutch had to turn to mobile wealth much earlier. The Netherlands were and are land poor. ${ }^{63}$ At the instant in which the post-Reformation public spheres in the Netherlands succeeded in creating an independent state, the Dutch were faced with the constant and difficult problems of finance and economic survival that the English did not have to face until the Civil Wars or thereafter. In the Dutch Republic, then,

${ }^{59}$ J. H. M. Salmon, Society in Crisis: France in the Sixteenth Century (New York, 1975); Mack Holt, The French Wars of Religion, 1562-1629 (Cambridge, 1995).

${ }^{60}$ We are not meaning to suggest that France witnessed only public controversy and debate during these two episodes. See, e.g., the lively discussion in Jeffrey Sawyer, Printed Poison (Berkeley, 1990).

${ }^{61}$ Orest Ranum, The Fronde: A French Revolution (New York, 1993).

${ }^{62}$ We are aware that French historiography, like its English counterpart, has had its revisionist moment. However, we have been persuaded by the more recent literature on the powers of the crown: Fanny Cosandey and Robert Descimon, L'absolutisme en France (Paris, 2002); Marie-Laure Legay, Les états provinciaux dans la construction de l'état moderne (Geneve, 2001); Julia Adams, The Familial State (Ithaca, NY, 2005).

${ }^{63}$ Jonathan Israel, The Dutch Republic (Oxford, 1995); Jan De Vries, Nederland, 1500-1815 (Amsterdam, 1995). 
the post-Reformation public spheres gave rise to something like what we are describing as the post-Revolutionary phase more rapidly than in England.

These heavily schematized comparisons are included for two reasons. First, we want to underline our belief that the English case is best understood by making comparisons with the histories of other European polities. And, second, we wish to emphasize that the account we are advancing here is not intended to revert to an old Whiggish story of English triumphalism and exceptionalism. ${ }^{64}$

\section{NEITHER REVISIONIST NOR WHIG}

By now it should be clear how our narrative differs substantively from both the revisionist and Whig accounts of early modern English triumphalism and exceptionalism. Our narrative differs substantively from the Whig account popularized by Thomas Macaulay and Trevelyan. It is worth recalling that both of these Whig historians argued that England avoided the fate of continental Europe in the nineteenth century because it achieved religious toleration and parliamentary supremacy in the seventeenth century through a bloodless, consensual, and aristocratic "revolution." "The English have for the last century and more been insistent that their revolution [of 1688-89] was unique-so unique as to have been practically no revolution at all," notes Crane Brinton, summarizing almost two centuries of Whig scholarship. ${ }^{65}$ Unlike these accounts, our narrative emphasizes the importance of politics out of doors, the centrality of social and institutional change in shaping the nature of political discussion, and the frequently intensely partisan nature of politics. Whereas the Whigs highlighted an English exceptionalism to explain the unique (and uncontinental) nature of English political development, our account emphasizes that the public spheres developed in England in ways not so different from the continental experience. In our view, had James II succeeded in completing his reconfiguration of the English state in the 1680s, English public political culture would have been remarkably similar to the political culture of Louis XIV's France.

We are, therefore, advancing a very different understanding of the emergence of "modernity" than that produced in Whig narratives. We agree with the Whig account that the early modern period in general, and early modern England in particular, was a transitional moment in European history. But we do not agree with the Whigs that there was only one path to modernity and one kind of modernity. Instead, we see modernization as necessarily contingent on a number of religious, political, economic, and institutional factors. The central characteristics of the modern state were bureaucratic capacity and local extension rather than the achievement of political liberty. Neither the state that emerged in France in the

\footnotetext{
${ }^{64}$ We are arguing that the English case is best understood in a European context. We are emphatically not telling a British story. Developments in Ireland and Scotland deserve their own narratives using the terms and concepts we have developed here if and when they are appropriate. Such narratives could then be juxtaposed. One study has recently made such comparisons: Tim Harris, Restoration: Charles II and his Kingdoms, 1660-1685 (London, 2005). We would also argue that the comparative approach needs to be applied within the conventional narratives of English history with crisis decades like the 1590 s and the 1620s or the 1670s being compared against one another as a means to gauge the nature and pace of change as well as to establish continuity or longer-term patterns of repetitions. See here Scott, England's Troubles.

${ }^{65}$ Crane Brinton, The Anatomy of Revolution, rev. and exp. ed. (New York, 1965), 19. Brinton originally made this claim in 1938.
} 
later seventeenth century nor the state that James II was in the process of creating accorded with a Whig definition of modernity. Both the French and Jacobite states were, however, decidedly new and in their own ways decidedly modern. They had the resources to fight wars on a scale unimaginable in the sixteenth century; they had new mechanisms to manipulate and agitate public opinion (the newly extensive post office, for example); and they had large bureaucracies that professionalized and nationalized governance. These states were easily distinguishable from the sort of state that had long existed in the United Provinces or the one that came into being in England after 1689. Both the Williamite state and the Jacobite state, we maintain, could be described as "modern." Each had a possible future in England as late as 1720. That the Jacobites failed to regain political dominance in England in the eighteenth century was by no means predictable or inevitable. Political contingency remains central to this account.

Unlike those of the revisionists, our narrative is a story of conflict as well as of the drive toward consensus; it is a story that locates politico-religious conflict beyond as well as within the court; and it is an account that highlights the importance of the creation of, and appeals to, publics beyond the landed elite. By deploying the concept of the public sphere, we are able to tell a dialectically coherent story of cumulative change that runs from the later sixteenth century through the eighteenth century. We are able to establish meaningful contact between histories and historiographies that have long been severed. The concept of the public sphere allows us to connect court-based political maneuvers, religious controversy, and then political economic debate with wider socioeconomic and institutional change. One of the great virtues of this narrative, it seems to us, is that we do not need to accord causal primacy to any one factor. We highlight the interaction of ideas, political and factional maneuver, and socioeconomic and institutional changes. ${ }^{66}$

We want to make clear, however, that ours is a project that hopes to build on rather than merely to refute the historiographical claims of the revisionists. We take seriously the revisionists' emphasis on religious conflict as a cause of political instability, their insistence on dynastic issues and the politics of the court as a central element in the politics of the period, their problematization of the categories of government and opposition, and, perhaps most importantly, their insistence on contingency. Our emphasis is on the modes of political communication and maneuver deployed by a variety of actors both inside and outside the establishment to deal with the potentially explosive consequences produced by the combination of confessional division, geopolitical crisis, and political economic controversy. By focusing on the methods and strategies of political communication rather than solely on the ideas communicated or the political ends pursued, we can identify and perhaps even start to explain changes in both popular politics and governance that are occluded by revisionist accounts of the same periods. Our account of the transformations of the public sphere makes clear that apparent political repetitions, whether in the form of baronial revolt or crises of popery and arbitrary government, must be understood as historically distinct events. In our account, the changing nature of political communication and action ensures that, despite the persistence

${ }^{66}$ Our dialectical approach bears strong similarities to the method deployed by Michael McKeon, The Origins of the English Novel (Baltimore, 1987), esp. 1-22. 
of political slogans or aims, the structure of the event and the nature of its outcome(s) necessarily could not be the same. ${ }^{67}$

Methodologically, we want to go beyond revisionist accounts in two ways. First, we want to reappropriate the deployment of contemporary printed materials. While we appreciate the force of revisionist criticisms of the use of printed sources by a previous generation of historians to give them unmediated access to contemporary social and political reality, we do not accept their consequent privileging of a certain sort of manuscript source. The notion of the public sphere, and the modes of political communication and action appropriate to it, provides us with the means to relate the contents of a variety of different kinds of polemical texts to social and political contexts. Printed works are a central, but by no means the only, form of polemical text with which historians of the public sphere should concern themselves. We need to remember the central role played by a variety of circulating manuscripts and images, of performances and collective political actions. ${ }^{68}$ In particular, the concept of the public sphere allows us to connect these polemical texts to the sorts of political narratives that revisionist historians were so keen to produce exclusively out of manuscript materials. In interpreting these sources, we insist on locating their deployment with social and political specificity. Printed works and political performances were unleashed in the public sphere at specific moments, in specific locations, with specific political, religious, or economic aims in mind. In making this point, we are merely drawing on the work of a range of historians and literary critics who have worked with the history of the book, the history of reading, and popular politics. ${ }^{69} \mathrm{We}$ want, in short, to reconfigure what we take to have been an overly rigid distinction that revisionists drew between representation and reality. We take the first task of the historian to be to situate socially and politically the stories contemporaries told about their circumstance rather than to evaluate immediately the truth value of those stories.

Second, whereas one of the basic moves of revisionism was to separate firmly political history from social and economic history, our approach tends in the opposite direction. ${ }^{70}$ One of revisionism's achievements was to restore autonomy to the political domain and to study it on its own terms. Our insistence on understanding the period in terms of the developing public sphere forces us to integrate political history with the histories of commercialization, literacy, institutional development, and extra-English affairs. By focusing on political communication, rather than nar-

\footnotetext{
${ }^{67}$ Jonathan Scott, Algernon Sidney and the Restoration Crisis (Cambridge, 1991), 6.

${ }^{68}$ Polemical texts in this period did not remain narrowly in one media form or another. Much recent work shows texts moving freely between printed and nonprinted media, from the pamphlet or printed ballad into petitions, oral tradition, or crowd behavior, and back again. See, e.g., Harris, London Crowds; Zaret, Origins; Hughes, Gangraena; Adam Fox, Oral and Literate Culture in England, 1500-1700 (Oxford, 2000). An awareness of these movements provides us with a broader context in which to situate printed materials. In our usage, the concept of the public sphere, as opposed to the conventionally deployed dichotomy of politics and society, allows us to capture fully the impact of the early modern polemical text in its various forms.

${ }^{69}$ For example, see Thomas Cogswell, The Blessed Revolution: English Politics and the Coming of War, 1621-1624 (Cambridge, 1989); Bellany, Politics of Court Scandal; Peacey, Politicians and Pamphleteers; Harris, London Crowds; Knights, Politics and Opinion.

${ }^{70}$ Our complaint here runs parallel to Keith Wrightson's concern about the direction of the new social history in "The Enclosure of English Social History," in Rethinking Social History, ed. Adrian Wilson (Manchester, 1993), 59-77.
} 
rowly on politics, we are compelled to consider historically relevant socioeconomic conditions that constrained and enabled communication and the institutions that facilitated (and even necessitated) different modes of communication, as well as the ideological content of the messages being sent out. Political communication was shaped by emerging markets and developing infrastructures of communication. ${ }^{71}$ While we insist that social and cultural conditions shaped the contours of political communication, we are not saying that socioeconomic developments determined political conflict in any straightforward and overdetermined way.

\section{CONCLUSION}

Our narrative, organized around the concept of the public sphere, is one of transformation. ${ }^{72}$ However, it is not one that points to the causes or consequences of a single revolutionary political event. Nor is it a narrative that insists that this revolutionary transformation was inevitable. Indeed, by separating the development of England's public sphere into various phases, we are bringing the contingency of those developments into sharp relief.

What then were the most important aspects of the transformations in the public sphere that we have described? First, we are emphasizing the sheer quantitative increase of public discussion. There was an exponential growth in the number of pamphlets, broadsides, and poems produced. The intensity and extent of political activity during the Civil Wars and the exclusion crisis have no parallels prior to 1640. Whereas the Elizabethan Bond of Association in the 1580s generated dozens of signatures in individual counties, that number pales in comparison to the hundreds of thousands of people that signed the 1696 Bond of Association in Lancashire alone..$^{73} \mathrm{~A}$ quantitative change of this magnitude represents, in fact, a profound qualitative change.

Second, the distinction we draw between the earlier and later public spheres is the difference between the episodic and the regular. The post-Reformation public sphere began as occasional and opportunistic openings and shuttings-down of debate on a limited set of issues. In many cases, this was initiated by the regime, or sometimes by elements within it, in order to generate support for its policies. Increasingly, the state was unable to put the genie back in the bottle, both because other, more or less oppositional forces saw the public sphere as a stage upon which they could air their grievances and circulate their complaints and because the public increasingly demanded information. In the 1640s and 1650s, the regularity with

\footnotetext{
${ }^{71}$ For instance, forthcoming work by both Susan Whyman and Lindsay O'Neill on the postal system and letter writing in early modern England will illuminate a vital element of English infrastructure. Here developments in the earlier period provided a crucial underpinning for the later burgeoning markets and more highly developed infrastructure for the distribution of news and cheap print. See Craig Muldrew, An Economy of Obligation (Basingstoke, 1998); Tessa Watt, Cheap Print and Popular Piety (Cambridge, 1991); Margaret Spufford, The Great Reclothing of Rural England (London, 1984), and Small Books and Pleasant Histories (Athens, GA, 1982). For the role played by communication in the public sphere in another national context, see Richard John, Spreading the News: The American Postal System from Franklin to Morse (Cambridge, MA, 1995).

${ }^{72}$ In some ways we are filling out the account first advanced by Lawrence Stone in "The Results of the English Revolutions of the Seventeenth Century," in Three British Revolutions, ed. J. G. A. Pocock (Princeton, NJ, 1980), 23-108.

${ }^{73}$ Pincus, epilogue to First Modern Revolution.
} 
which both sides (and factions within each group) appealed to the public transformed the occasional into the normal. This regularity created political actors with an increasingly self-conscious and sophisticated sense of the way to play politics in this new public arena. ${ }^{74}$ This in itself made certain that political struggles in the second half of the century were conducted differently from political struggles in the first half. Many appreciated the political value of appeals to the public, while denying that free and open public, political discussion was inevitable or desirable. James II and various members of his political circle, for example, were adept at advertising their policy initiatives to the public while at the same time effectively clamping down on political communication initiated by their critics. Only after 1688-89 did the vastly expanded financial institutions of the government, and the need that the government had to keep open channels of political economic communication for the sake of those very institutions, compel the state to accept the public sphere as a regular, rather than exceptional, phenomenon.

Third, our account points to the shifting geographic and social location of the public sphere. The quantitative expansion of the public sphere in England's early modern period necessarily meant that an increasingly wide array of people was brought within the nexus of political communication. This quantitative shift meant that people below the level of the landed elite gained access to various forms of political information, both because they wanted that access and because political factions had much to gain from mobilizing them. While London had always been at the center of networks of political information, political communication outside of London was not limited to the towns. News sheets and separates were more likely to be circulated through the country houses of the landed elite. ${ }^{75}$ Religious controversy could surface not only in rural parish churches but also in the myriad voluntary associations and networks of the godly, both Protestant and Catholic. ${ }^{76}$ The growth in the size and number of towns over the course of the seventeenth century created new centers of the public sphere, such as the coffeehouse. Critics have demonstrated the specifically urban character of the new literary genre of the novel. ${ }^{77}$

Fourth, while participants in the post-Reformation public spheres considered political communication to be a necessary evil, by the end of our period many (though by no means all) political actors understood relatively unfettered public discussion to be normatively desirable. ${ }^{78}$ Controversialists opened post-Reformation public spheres as a means of establishing the truth against imperfectly reformed or politically degraded opponents. Once polemical and political victory was achieved, these actors imagined that the public discussion had served its ephemeral purpose. In the post-

\footnotetext{
${ }^{74}$ Nigel Smith, in Literature and Revolution, is describing exactly this phenomenon when he highlights the emergence of new literary genres between 1640 and 1660.

${ }^{75}$ Susan Whyman, Sociability and Power in Late-Stuart England (Oxford, 1999).

${ }^{76}$ The prophesyings of the Elizabethan church were suppressed because they allegedly provoked popular debate and therefore disorder. David Como's account of the Grindletonians locates the growth of this sect in a remote, jurisdictionally complex part of the Pennines connected directly to London through cloth-trade routes and the personal networks of the godly. David Como, Blown by the Spirit (Stanford, CA, 2004), chap. 8. Patrick Collinson's remarks on the Protestant town as a center for sociability and communication in Birthpangs of Protestant England are also suggestive on this subject.

${ }^{77}$ Ian Watt, The Rise of the Novel (Berkeley, 1957); J. Paul Hunter, Before Novels (New York, 1990); McKeon, Origins of the English Novel.

${ }^{78}$ John Brewer, Party Ideology and Popular Politics at the Accession of George III (Cambridge, 1976).
} 
Revolutionary period not only did actors perceive the existence of the public sphere as the normal state of affairs; some came to see that state of affairs as a positive good. Religious, political, and political economic dispute, in the view of commentators such as John Locke and Daniel Defoe, could lead, in itself, to the discovery of a truth distinct from the positions initially enunciated by the disputants.

Participants in this public sphere were under no illusion that each individual utterance in that sphere would be rational. Indeed, under the license of public partisanship, the political slur reached new quantitative and qualitative heights in the period, but at least some contemporaries maintained the illusion that the cut and thrust of debate would reveal better political options. ${ }^{79}$ Political and religious conspiracy theories did not disappear in the period (nor have they now); in fact, the anxieties created in part by the pace of change in the public sphere and by the intensity of increasingly party-based political conflict caused many contemporaries to resort to them with increased fervor. ${ }^{80}$

Fifth, the later period was distinguished from the post-Reformation public sphere by the emergence of "political economy" as a central autonomous element in public controversy. Our claim is not that discussions of commerce emerged for the first time after the Civil Wars but rather that their quantitative ubiquity in the later period infused the language of politics so as to create a qualitative shift in political communication, reaching out to publics beyond Parliament, the Privy Council, or members of the joint-stock companies. Political economy did not replace discussions of religion or geopolitics. These issues remained, and still remain, crucial elements of public discussion. Our discussion of the public sphere modifies Habermas's story in a number of important ways. To begin with, we suggest that the practices and procedures that constituted the post-Reformation public sphere were a necessary prerequisite for the emergence of the post-Revolutionary public sphere, not only in England but throughout Europe. The existence of the post-Reformation public sphere did not make the later developments sketched here inevitable, but it did make them possible. The midcentury crisis itself would not have taken the form it did without the previous existence of the political forms of maneuver and communication of the post-Reformation period. The robust discussion of political economy characteristic of the post-Revolutionary public sphere depended on these earlier developments.

At the least, this suggests that the crisis of capitalism of the sort described by Habermas could not in and of itself have generated the kind of post-Revolutionary public sphere described here. Habermas argues that a crisis of capitalism, a bitter struggle between finance and manufacturing interests, forced each side to appeal to and create publics to settle their differences. ${ }^{81}$ In the period after 1688, it is hard to find a conflict between manufacturing and finance capitalism. Instead, both the supporters of the Bank of England and England's manufacturing interests by and large aligned themselves in print and polemic behind the notion of an infinitely

\footnotetext{
${ }^{79}$ See Knights, Representation and Misrepresentation; Rachel Weil, "'If I did say so, I lyed': Elizabeth Cellier and the Construction of Credibility in the Popish Plot Crisis," in Political Culture and Cultural Politics in Early Modern England, ed. Susan Amussen and Mark Kishlansky (Manchester, 1995), 189-209.

${ }^{80}$ See Rachel Weil, "The Politics of Legitimacy: Women and the Warming Pan," in The Revolution of 1688-89, ed. Lois Schwoerer (Cambridge, 1992), 65-82.

${ }^{81}$ Habermas, Structural Transformation, 14-20, 57-58, 144.
} 
expandable political economy based on labor. Their opponents, supporters of the East India and African companies - and various agrarian interests aligned against the growing manufacturing sector-defended a vision of a finite political economy based on land. In both cases economic self-interest was melded with a sophisticated geopolitical, sociopolitical, and (at times) religious vision. This ideological contest was always near the center of the political controversies of the 1680s, 1690s, and the early decades of the eighteenth century. ${ }^{82}$

Finally, unlike Habermas's account, our story insists on the central role played by an increasingly powerful state. In the earlier period, we see a state, perceiving itself to be under dynastic, confessional, and socioeconomic threat, resorting to various modes of political communication and invoking various publics to shore up its position. It was the division of the state at midcentury, both instantiating regular invocations of the public sphere and placing larger and larger demands on an everwidening public, that arguably began the transformation from the post-Reformation to the post-Revolutionary public sphere. We want to caution that, even at that point, the public sphere had a tenuous existence still tied to the ebb and flow of political conflict and crisis. It was only in the 1690s and thereafter that the political struggle over how best to feed the voracious appetite of a now greatly expanded state apparatus rendered such public discussion a permanent feature of political life. ${ }^{83}$

We conclude with a final paradox. We see different paths, and indeed different political modernities or public spheres, emerging out of the circulation (in part) of conspiracy theories and more or less unsubstantiated political rumors. It was these conspiracy theories, or ideologies, that created the political energy that exploded in the crisis of midcentury. It was also different but related sorts of conspiracy theories, in this case competing claims about French and Dutch aspirations for universal dominion, that gave force to the political economic conflict that so influenced the replacement of James II with William III. ${ }^{84}$

\footnotetext{
${ }^{82}$ Pincus, "The State and Civil Society," and First Modern Revolution.

${ }^{83}$ John Brewer, The Sinews of Power (New York, 1988); Michael Braddick, State Formation in Early Modern England, c. 1550-1700 (Cambridge, 2000).

${ }^{84}$ Steve Pincus, "From Butterboxes to Wooden Shoes: The Shift in English Popular Sentiment from Anti-Dutch to Anti-French in the 1670s," Historical Journal 38 (1995): 333-61, "The English Debate over Universal Monarchy," in A Union for Empire, ed. John Robertson (Cambridge, 1995), 37-62, and "To Protect English Liberties': The English Nationalist Revolution, 1688-89," in Protestantism and National Identity: Britain and Ireland, c.1650-c.1850, ed. Tony Claydon and Ian McBride (Cambridge, 1998), 75-104.
} 